\title{
Intracapsular dexamethasone implant in patients undergoing phacoemulsification and intraocular lens implantation
}

\author{
Implante intracapsular de dexametasona em pacientes submetidos a facoemulsificação \\ e implante de lente intraocular
}

Lucas Monferrari Monteiro Vianna ${ }^{1}$, Lincoln Leme Freitas ${ }^{1}$, Walton Nosé ${ }^{1}$, Lillane Andrade Almeida Kanecadan ${ }^{1}$, Eduardo Sone Soriano ${ }^{1}$, Cristina Muccioli ${ }^{1}$, Rubens Belfort JR. ${ }^{1}$

\begin{abstract}
Purpose: To relate the outcomes of 7 eyes of 7 patients in which a dexamethasone 0.7 mg implant $\left(\mathrm{Ozurdex}^{\circledR}\right)$ was placed inside the capsule bag after phacoemulsification and intraocular lens (IOL) implantation and compare with the fellow eyes, that were operated by the same technique and received dexamethasone eyedrops in the post-operatory.

Methods: Report review of 7 eyes of 7 patients who received dexamethasone $0.7 \mathrm{mg}$ implant after phacoemulsification and $\mathrm{IOL}$, comparing them to the fellow eyes. All the patients underwent bilateral cataract surgery, with one month interval, by the same technique and by experienced surgeons, without complications. Post operatory medication consisted of moxifloxacin eye drops for all the 14 eyes and topic dexamethasone for the 7 eyes that did not received the implant.

Results: Nuclear cataract classification (according to LOCS III) was $3.28 \pm 0.69$ in the implant eye group and $3.14 \pm 0.83$ in the fellow eye group. Postoperative best spectacle correct visual acuity (BSCVA) was $0.85 \pm 0.12$ and $0.87 \pm 0.13$, respectively in the implant and fellow eye groups. The intraocular pressure remained stable and similar to the pre-operative measurements. Anterior chamber reaction and cornea edema were similar in both groups in the follow-up. Two of the four no sutured pellet migrated to the anterior chamber during the first post-operative week and had to be repositioned. Another no sutured pellet dislocated and remained partially inside the capsule bag. The 3 patients with $\mathrm{OL}$ haptic-sutured pellet had no complications.
\end{abstract}

Conclusions: In the present study, dexamethasone $0.7 \mathrm{mg}$ implant were effective in controlling the inflammation after phacoemulsification and $1 O \mathrm{~L}$ implantation, with no significant side effects.

Keywords: Cataract/classification; Dexamethasone/administration \& dosage; Administration, topical; Phacoemulsification

\section{RESUMO}

Objetivos: Relatar os resultados de 7 olhos de 7 pacientes em que foi realizado o implante de dexametasona $0,7 \mathrm{mg}\left(\mathrm{Ozurde}^{\circledR}\right)$ no saco capsular após facoemulsificação e implante de lente intraocular (LIO) e comparar com os olhos contralaterais, que foram operados pela mesma técnica e receberam colírio de dexametasona no pós-operatório.

Métodos: Relato de casos de 7 olhos de 7 pacientes que receberam o implante de dexametasona 0,7 mg após facoemulsificação e implante de L1O, comparando-os com os olhos contralaterais. Todos os pacientes foram submetidos a cirurgia de catarata bilateral, com intervalo de um mês entre as cirurgias, pela mesma técnica, por cirurgiões experientes e sem complicações. No pós-operatório foi utilizado colírio de moxifloxacino em todos os 14 olhos e dexametasona tópica nos olhos que não receberam o implante.

Resultados: A classificação da catarata de acordo como LOCS III foi de 3,28 $\pm 0,69$ no grupo que recebeu o implante $3,14 \pm 0,83$ no grupo de olhos contralateral. A acuidade visual com melhor correção foi de 0,85 00,12 e 0,87 $\pm 0,13$ respectivamente nos grupos com e sem implante. A pressão intraocular permaneceu estável e similar aos valores pré-operatórios. A reação de câmara anterior e o edema de córnea foram similares nos dois grupos. Dois dos 4 implantes sem sutura migraram para a câmara anterior durante a primeira semana de pós-operatório e necessitaram de reposicionamento. Outro implante sem sutura teve deslocamento e permaneceu parcialmente dentro do saco capsular. Os 3 pacientes com implante suturado não tiveram complicações. Conclusão: No presente estudo, o implante de dexametasona 0,7 mg foi efetivo no controle da inflamação intraocular após cirurgia de facoemulsificação e implante de LIO, sem efeitos colaterais significativos.

Descritores: Catarata/classificação; Dexametasona/administração \& dosagem; Administração tópica; Facoemulsificação

\section{INTRODUCTION}

Topical anti-inflammatory drugs usually associated to antibiotics continues to be the standard practice to reduce the inflammation resulting from intraocular surgery in spite disadvantages related to poor corneal penetration, difficulties with patient's compliance and ocular toxicity ${ }^{(1-3)}$.

Ozurdex ${ }^{\circledR} 0.7 \mathrm{mg}$ (dexamethasone $0.7 \mathrm{mg}$ implant) is a $0.46 \mathrm{~mm}$ in diameter and $6 \mathrm{~mm}$ in length FDA approved biodegradable implant to be injected into the eye (vitreous) to treat different retinal and uveal pathologies. Several studies have shown that it's a safety and efficient dispositive ${ }^{(4)}$. It has also been used off label to treat non necrotizing non infectious scleritis(5)

\section{METHODS}

Report review of 7 eyes of 7 patients who received a fragment of dexamethasone $0.7 \mathrm{mg}$ implant after phacoemulsification and hydrophilic foldable IOL (Type 7B, Alcon ${ }^{\circledR}$ ) implantation at the São Paulo Hospital, Federal University of São Paulo, comparing them to the fellow eyes. All the patients underwent bilateral cataract surgery,

Submitted for publication: April 4, 2013

Study carried out at Vision Institute and Ophthalmology Department, Universidade Federal de São Paulo - UNIFESP - São Paulo (SP), Brazil.

Physician, Vision Institute and Ophthalmology Department, Universidade Federal de São Paulo UNIFESP - São Paulo (SP), Brazil.

Funding: No specific financial support was available for this study.

Disclosure of potential conflicts of interest: L.M.M.Vianna, None; L.L.Freitas, None; W.Nosé, None; L.A.A.Kanecadan, None; E.S.Soriano, None; C.Muccioli, None; R.Belfort Jr, None.

Correspondence address: Lucas Monferrari Monteiro Vianna. Rua Botucatu, 821 - São Paulo (SP), 04023-900 - Brazil - E-mail: lucasmmvianna@yahoo.com.br

Aprovado pelo Comitê de Ética Médica da UNIFESP através da Plataforma Brasil sob número 15199 
with one month interval, by the same technique and by experienced surgeons, without complications. Cataracts were graded according to the "Lens Opacities Classification System" III (LOCS III) ${ }^{(6)}$. Patients were aged 58 to 71 years old. None of them had glaucoma or others ophthalmologic diseases.

Four eyes received a half pellet of the implant ( $3 \mathrm{~mm}$ ) inside the bag, positioned between one of the IOL's haptic and the equator of the capsular bag, without suturing. Three eyes received one-third pellet of the implant $(2 \mathrm{~mm})$, sutured to one of the IOL haptic with nylon 10.0. Postoperatory medication consisted of moxifloxacin eye drops, four times a day, during one week for all the 14 eyes and topic dexamethasone for the 7 eyes that did not received the implant. Patients were followed with biomicroscopy, tonometry and ophthalmoscopy on days 1, 3, 7, 30, 60 and 90 after surgery. Wide scanning angle Ultrasound Bio Microscopy (UBM) (50-MHz transducer, immersion technique, Vumax II, Sonomed) was used to evaluate the operated eyes on day 2. Anterior chamber reaction was graded according to SUN Working Group ${ }^{(7)}$. None of them had glaucoma or others ophthalmologic diseases.

The study was approved by the Institutional Review Board and followed the tenets of the Declaration of Helsinki. None of the patients had any expenses with the treatment and none of the authors received any type of compensation, including financial for the study.

\section{RESULTS}

Nuclear cataract classification (according to LOCS III) was 3.28 \pm 0.69 in the implant eye group and $3.14 \pm 0.83$ in the fellow eye group, varying from 2 to 4 in both groups. In the first day, the cornea edema was $1.0 \pm 0.53$ in average in both groups and no detectable corneal edema in none of groups from the seventh day on. Preoperative best spectacle correct visual acuity (BSCVA) using Snellen chart was $0.25 \pm 0.11$ in the implant group and $0.27 \pm 0.13$ in the fellow eye group. On the third month postoperative, BSCVA was $0.85 \pm 0.12$ and $0.87 \pm 0.13$, respectively. The intraocular pressure $(\mathrm{IOP})$ remained stable and similar to the preoperative measurements during the postoperative visits. Anterior chamber reaction (ACR) is shown in figure 1.

The UBM performed on day 2 showed the positioning of the implant and its relations with the iris, IOL haptic and the capsular bag (Figure 2).

Two of the four no sutured pellet migrated to the anterior chamber during the first post-operative week and had to be repositioned (Figure 3). Another no sutured pellet dislocated and remained partially inside the capsule bag (Figure 4). The 3 patients with IOL haptic-sutured pellet had no complications.

\section{DISCUSSION}

Reducing or eliminating the responsibility of administering postoperative anti-inflammatory drops would be a significant benefit to patients since lack of drug compliance is frequent.

The ideal postoperative drug delivery system for cataract surgery should have high and prolonged drug level only at the desired site, with safety and short-acting enough to diminish the risks from side effects or allergy ${ }^{(8)}$. Topical anti-inflammatory medication after cataract surgery continues to be the standard practice, but it does not have some of this related attributes. The intraocular absorption of the topical preparation is low, with fluctuations in the anterior chamber concentration and may be absorbed systemically by the nasal and gastric mucosa ${ }^{(9)}$. Options like subconjunctival injection, collagen shield and intracameral injection fail to provide a therapeutic drug level of more than several hours ${ }^{(1)}$. Drugs like Surodex (Oculex Pharmaceuticals, Inc., Sunnyvale, CA) containing dexamethasone 60 micrograms was used after phacoemulsification and its safety and efficacy has been related in the literature ${ }^{(8,10)}$.

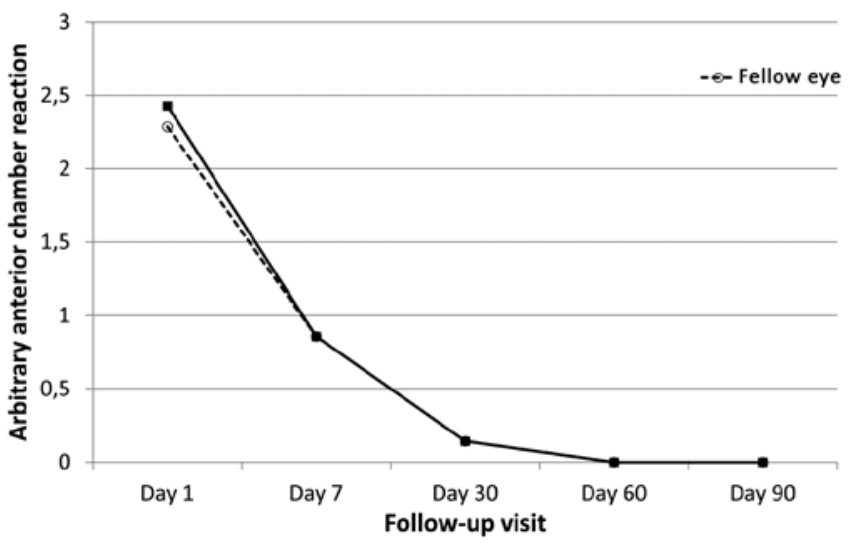

Figure 1. Average clinical assessment of anterior chamber reaction in the group with dexamethasone implant and in the fellow eye (control). Anterior chamber reaction was graded according to SUN Working Group ${ }^{(7)}$.

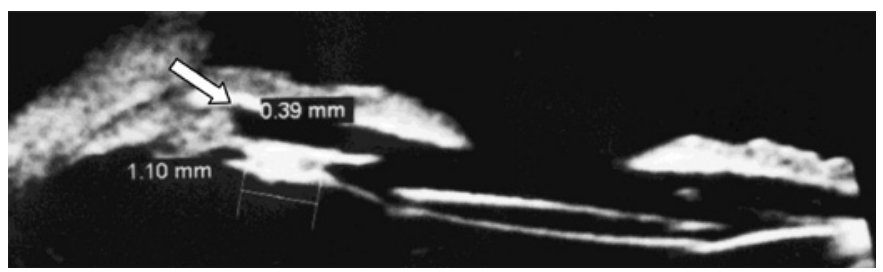

Figure 2. Dexamethasone $0.7 \mathrm{mg}$ implant and its relations with the iris, IOL haptic and the capsular bag.
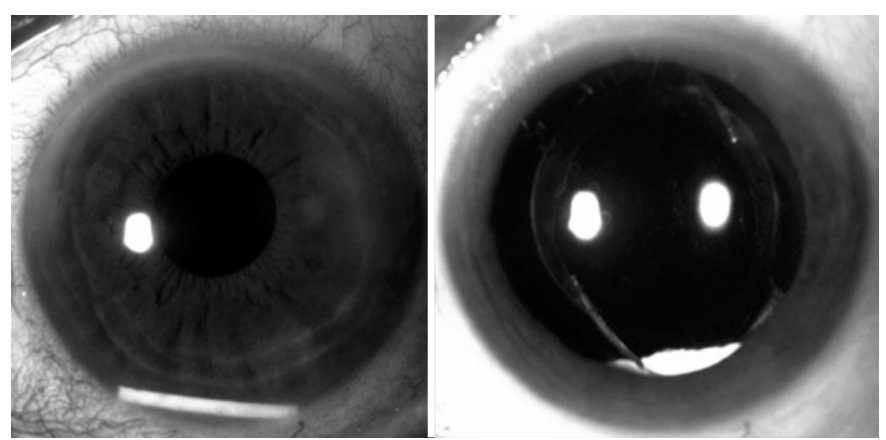

Figure 3. Dexamethasone $0.7 \mathrm{mg}$ implant migration to the anterior chamber before and after repositioning.
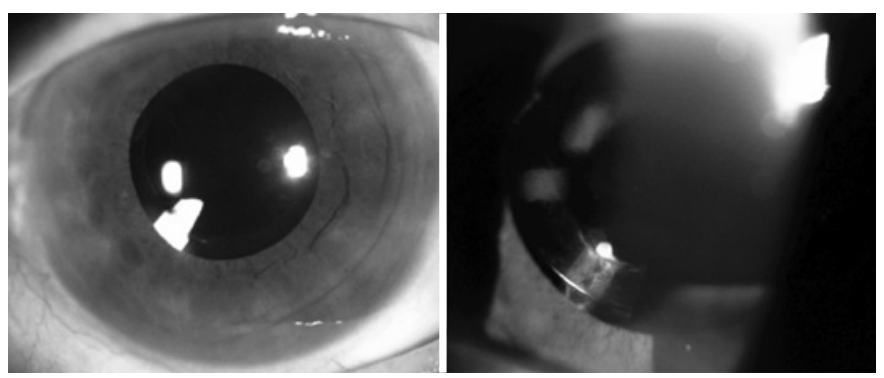

Figure 4. Non-sutured pellet on days 7 (left) and 90 (right) postoperative. 
In our study we have reported the outcomes of 7 patients who received a dexamethasone $0.7 \mathrm{mg}$ implant inside the bag after phacoemulsification and IOL implantation.

Clinical slit-lamp assessment of anterior chamber flare and cells showed normal follow-up for the postoperative comparing with eye drops corticosteroids in the fellow eye. Chang et al. ${ }^{(11)}$ report that rescue medication was required for intraocular inflammation in 12\% of patients with a Surodex ${ }^{\circledR}$ implant by the end of a 2-month study. We found no rebound inflammation in the seven patients and there were no need of corticosteroids eye drops complementation in any of them.

The IOP remained stable during all the follow-up visits and were similar to the fellow eye. There were no needs of antihypertensive medications in any of the patients.

No significant edema was detected in any of the follow-up visits. BSCVA was better than preoperative in all the seven patients and were similar to the fellow eye.

An ultrasound biomicroscopy (UBM) was performed on day 2 to evaluate the positioning of the implant in the non-dilated eye (Figure 3). Since there are reports of Surodex migration and remnants in the anterior chamber in the literature ${ }^{(8,10)}$. In our study, the dexamethasone $0.7 \mathrm{mg}$ implant was placed sutureless in the first four patients and there was a migration to the anterior chamber in two of them and a migration from the original intraoperative position in another one, almost reaching the visual axis (Figure 4). Because of this, the other 3 implants were sutured on the IOL haptic and remained stable throughout the follow-up.

Larger series would be necessary to compare the potential benefits of reduced systemic side effects and toxicity of dexamethasone implant after phacoemulsification.

\section{ACKNOWLEDGEMENTS}

Flávio Hirai, MD, PhD.

\section{REFERENCES}

1. Kamal S. Steroid depot injection versus postoperative steroid eyedrops to prevent inflammation and macular edema after cataract surgery. J Cataract Refract Surg. 2012;38(1):186; author reply 187. Comment on Dieleman M, Wubbels RJ, van KootenNoordzij M, de Waard PW. J Cataract Refract Surg. 2011:37(9):1589-97.

2. Negi AK, Browning AC, Vernon SA. Single perioperative triamcinolone injection versus standard postoperative steroid drops after uneventful phacoemulsification surgery: Randomized controlled trial. J Cataract Refract Surg. 2006:32(3):468-74.

3. Braich PS, Almeida DR, Hollands S, Coleman MT. Effects of pictograms in educating 3 distinct low-literacy populations on the use of postoperative cataract medication. Can J Ophthalmol. 2011;46(3):276-81.

4. London NJ, Chiang A, Haller JA. The dexamethasone drug delivery system: indications and evidence. Adv Ther. 2011;28(5):351-66.

5. Nascimento H, França M, García LG, Muccioli C, Belfort R Jr. Subconjunctival dexamethasone implant for non-necrotizing scleritis. J Ophthalmic Inflamm Infect. 2013;3(1):7.

6. Chylack LT Jr, Wolfe JK, Singer DM, Leske MC, Bullimore MA, Bailey IL, et al. The Lens Opacities Classification System III. The Longitudinal Study of Cataract Study Group. Arch Ophthalmol. 1993;111(6):831-6.

7. Jabs DA, Nussenblatt RB, Rosenbaum JT:Standardization of Uveitis Nomenclature (SUN) Working Group. Standardization of uveitis nomenclature for reporting clinical data. Results of the First International Workshop. Am J Ophthalmol. 2005;140(3):509-16.

8. Chang D, Wong $\vee V$. Two clinical trials of an intraocular steroid delivery system for cataract surgery. Am J Ophthalmol. 2000;129(5):703-4.

9. Bodor N. Designing safer ophthalmic drugs by soft drug approaches. J Ocul Pharmacol. 1994;10(1):3-15.

10. Wadood AC, Armbrecht AM, Aspinall PA, Dhillon B. Safety and efficacy of a dexamethasone anterior segment drug delivery system in patients after phacoemulsification. J Cataract Refract Surg. 2004;30(4):761-8. Comment in J Cataract Refract Surg. 2005 Aug; 31(8):1479-80.

11. Chang DF, Garcia IH, Hunkeler JD, Minas T. Phase II results of an intraocular steroid delivery system for cataract surgery. Ophthalmology. 1999;106(6):1172-7. 